\title{
Improving public library service quality in local city of Indonesia
}

\author{
Prima Fithri*, Afri Adnan, and Verra Syahmer \\ Department of Industrial Engineering, Faculty of Engineering, University of Andalas, Padang
}

\begin{abstract}
The purpose of this study is to investigate the gap between perceptions and expectations of users on the services of West Sumatera Province Library as a public sector and determine the priority level of the requirements for the library in order to improve the quality of services based on the dimensions of the service quality. This was done using Servqual and Quality Function Deployment (QFD) method. It was found that, from overall attributes, only one attribute fulfills users' expectations (it has a positive gap), tangibles element for the attribute of cool air circulation. The ranking of the gap, for all dimensions, is the dimension of responsiveness, assurance, empathy, tangibles and reliability. It indicates that users's expectations were not being fulfilled yet. The main benefit of this research is to understand user's perceptions and expectations towards the services provided and to obtain the improvement priority to be taken by the West Sumatera Province Library.
\end{abstract}

\section{Introduction}

For many years libraries were major players in the information industry, dominating the field for centuries (Snoj and Petermanec, 2001). According to Line (Jordan, 1998, p.31) library responsibility are limited to collecting and processing prosedures and they engaged almost exclusively with themselves. They did not affected by the pressure from market forces and their profit did not depend on the successful selling of their services. Successful marketing depends on customer satisfaction. Nowadays, many researchers and practitioners concern about customer satisfaction in library (Hiller, 2001:606; Nitecki and Franklin, 1999:485; Allen, Ward, Wary and Lopez, 2003:138; Martensen and Granholdt, 2003:140; Calvert, 1998:296; Harwood and Bydder, 1998:161; Shi, Holahan, and Jurkat, 2004:122). Although user satisfaction is not an unfamiliar topic in library science, especially in university libraries (Thapisa, 1999; Luca, 2006; Kiran 2006; Mehran, 2008; Snoj and Pertamanec, 2001), there are not many research in the area of public library user satisfaction.

Padang, a local city of West Sumatera in Indonesia has one public library. Students, academicians, practitioners, and citizens use this library to get some information that they need. According to Deputy Development Resource Library at the National Library of Indonesia Republic, Supriyono, before the earthquake hit in 2009 West Sumatera province Library is one of four best libraries in Indonesia. Nowadays it's just a collapsed library, many collections and infrastructure were damaged or destroyed. The effort to rebuild West Sumatera province library reputation cannot completely depend on the others. West Sumatera province library need to promote quality services to produce continuous improvement on its performance. Performance improvements can be implemented through service factors enhancement which can be used to help deliver satisfaction and value added as well as bring a good image for the library.

If viewed from customer perspective, it is recognized that different backgrounds in terms of economic, educational, society etc can form the perceptions and expectations to library services in West Sumatera province. This study try to investigate the gap between perceptions and expectations of users on the services of West Sumatera Province Library. This study also determine the priority level of the requirements for the library in order to improve the quality of services based on the service quality dimensions. Therefore, perception and expectation aspects of consumers should be captured by the library workers in order to show good service as an effort to provide quality services that suit with consumer needs.

In recent years the service has grown dramatically. This resulted in various service industries that exists today, such as employment services, hospitals and schools offered by the government, airline services, entertainment companies and banks that offered by private non-profit organizations (Kotler and Armstrong, 2008).

According to Goetsch and Davis, 1994 (Tjiptono and Diana, 2003), quality is defined as an effort made to meet or exceed customer expectations that include products, services, people, processes and environments with changing conditions over time.

\section{Research Methodology}

In this research, data are obtained from questionnaires and interviews. The questionnaire addressed to users of the circulation and reference of West Sumatera Province library. After designing the questionnaire, a pilot test

\footnotetext{
* Corresponding author: author@e-mail.org
} 
conducted to analyze whether the questionnaire is valid and reliable. The distribution of the questionnaire conducted in accordance with the number of samples that have been calculated before. Interviews are used to obtain preliminary data in this study.

Data from questionnaire are used as input for QFD and Servqual, to calculate the value gap and the importance of each service attribute of West Sumatera public Library.

a. Data collection

Questionnaire are giving directly to respondents and researcher may give instructions or assistance directly to the respondent if the respondent had difficulty in filling out the questionnaire.

b. The number of questionnaire

97 questionnaire are used for this study. 92 questionnaire filled out by respondents and 5 questionnaire filled by the Library employees. 5 questionnaire filled by library employees used as pilot test. Data processing consists of three stages:

1. Validity and reliability test.

2. The Calculation of Servqual

Servqual used to calculate gap between the variables examined and any attributes that are experiencing a gap. In this study it has been established that the gap between user perceptions with user expectations as Gap 5. The calculation of Gap 5 follow this formula:

Gap $5=$ average user perceptions - average user expectation

3. The Calculation of QFD

QFD can help the company meet customer expectations to improve the quality of service provided. QFD is part of product planning which translate customer requirements into engineering characteristics. HQ phase I create using this following steps:

a. Calculate the level of customer interest

b. Determine the technical characteristics

c. Determine the relation between consumer needs and the characteristics of engineering using relationship matrix

d. Calculating the priority of engineering characteristics

e. Determining correlation technique

From the analysis, the gap between the expectations and perceptions of the services quality can be determined and to improve what needs to be done to meet the user expectations. After the analysis, the conclusion can be drawn from this study. Suggestions could be put forward to improve the services provided.

\section{Finding and Result}

The finding and results are presented in two parts: Importance Performance Analysis and HOQ/House of Quality. However, pre-analysis was performed to determine the validity and reliability of the data gathered using the questionnaires from the population of 97 individuals. This research showed that the data and items collected for measuring customer satisfaction toward the product quality and service quality for perceived condition, and desired condition were valid and reliable. This data was then being processed using IPA and HOQ method.

\subsection{Importance Performance Analysis}

The steps used in applying the IPA method are as follows:

1. Determine the level of compatibility between the interest rate and the level of satisfaction by comparing scores with the score of interest.

Processing the data using Importance Performance Analysis (IPA) consists of calculating the level of suitability and defines the results obtained in the Cartesian diagram. The first step is to measure the level of suitability. Level of suitability is the ratio between the perceived condition score with the score level desired condition. The levels of suitability are divided into three level; $0-65 \%$ for unsatisfied; $66 \%$ $100 \%$ for less satisfied; and more than $100 \%$ for very satisfied. 16 questions are used to calculate the level of suitability between perceived and desired conditions for product quality; 5 questions are unsatisfied and 11 questions are less satisfied. Furthermore, 14 questions are used for service quality; 2 questions are unsatisfied, 6 questions are less satisfied, and 6 questions are satisfied. The average level of suitability between perceived and desired conditions for service quality is $78 \%$ and for service quality is $76 \%$.

2. Calculate the average for each attribute that is perceived by the respondents.

For each questions, the average values of customers' interest and satisfaction were computed. Those values are then plotted in a Cartesian diagram. The horizontal axis of the diagram is the average of satisfaction level and its vertical axis is the average of interest level. The diagram is then divided into 4 quadrants. Analyses are focused on quadrant I and III which represent the highest level of interest and the lowest level of satisfaction. The scores were plotted into four quadrants and each quadrant covers related sub indicators as described in Figure 1 for product quality and Figure 2 for service quality. Sub indicators highlighted in quadrants I and III should be the greatest priority for improvement. The sub indicators in quadrants I and III for product quality are building quality, location factors, facilities and infrastructure and for service quality the sub indicators are reliability, assurance, and responsiveness.

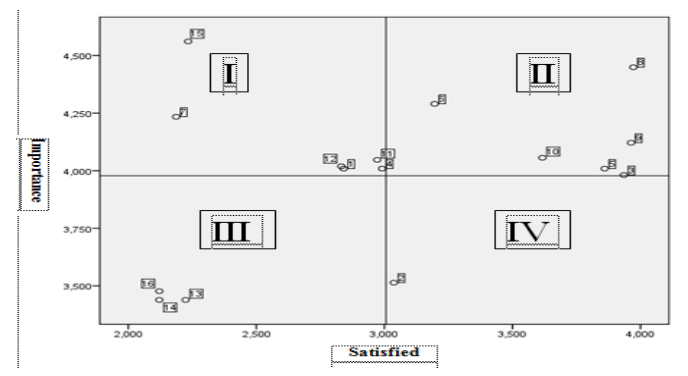

Fig.1. Cartesian Diagram of Product Quality 


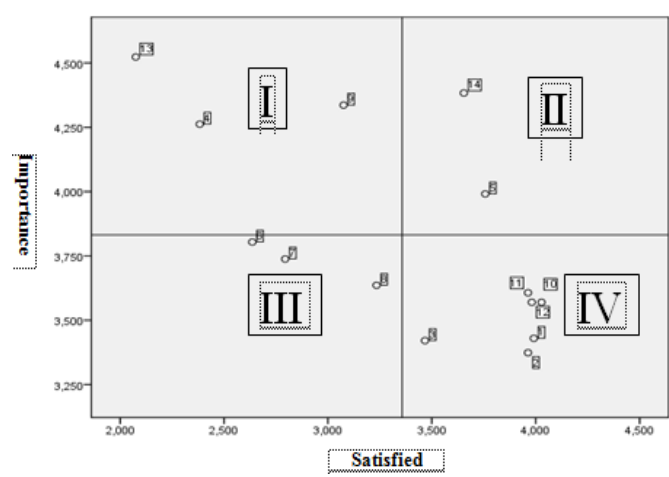

Fig 2. Cartesian Diagram for Service Quality

\subsection{House of Quality}

The steps used in applying the HOQ method are as follows:

1. Voice of Customer

Sub indicators obtained in quadrant I and III of Cartesian diagram for product and service quality are applied to build the House of Quality. The sub indicators will be transformed into the voice of customers.

2. Technical Characteristics

The needs of customers have to be responded technically by the home developer to increase the satisfaction level of customers. The technical characteristics are defined based on the interview conducted with the architects working in the company. The next step is to correlate the voices of customer and the technical characteristics in the form of a correlation matrix.

3. Technical Characteristics Priority

Sometimes it is almost difficult to accommodate all the technical characteristics at the same time and therefore should be ranked according its priority. The processes to ordering the priority are calculated by multiplying the interest rate of costumers with the value of the matrix of relationship $(0,1,3$ and 9$)$. The result is shown in Table 1.

Table 1 Priority of Technical Characteristics Score

\begin{tabular}{|c|c|c|c|}
\hline $\begin{array}{l}\mathbf{N} \\
\mathbf{0}\end{array}$ & Technical Characteristic & $\begin{array}{c}\text { Voice of } \\
\text { Costumer (VOC) }\end{array}$ & 离 \\
\hline 1 & $\begin{array}{l}\text { Provide free renovations for a month } \\
\text { after the handover of house key }\end{array}$ & $\begin{array}{l}\text { Warrants within a specified period to } \\
\text { prospective residents }\end{array}$ & 21.94 \\
\hline \multirow{2}{*}{2} & \multirow{2}{*}{$\begin{array}{c}\text { Carry out routine maintenance and } \\
\text { drainage cleaning }\end{array}$} & $\begin{array}{l}\text { Locations of the houses were not } \\
\text { flooded in the rainy weather }\end{array}$ & \multirow{2}{*}{20.08} \\
\hline & & $\begin{array}{l}\text { The availability of rain water disposal } \\
\text { facilities / drainage }\end{array}$ & \\
\hline 3 & $\begin{array}{c}\text { Casting and improving road quality } \\
\text { on a regular basis }\end{array}$ & $\begin{array}{c}\text { The ease of movement around the } \\
\text { houses and are not damaged }\end{array}$ & 19.49 \\
\hline \multirow[t]{2}{*}{4} & \multirow{2}{*}{$\begin{array}{c}\text { Intense coordination with sub- } \\
\text { contractor that } \\
\text { handles the } \\
\text { houses construction }\end{array}$} & $\begin{array}{c}\text { The buildings were not damaged during } \\
\text { the } \\
\text { earthquake }\end{array}$ & \multirow[t]{2}{*}{19.44} \\
\hline & & The roof of the houses do not easily leak & \\
\hline \multirow{2}{*}{5} & \multirow{2}{*}{$\begin{array}{c}\text { Provide forms for critiques and } \\
\text { suggestions }\end{array}$} & $\begin{array}{l}\text { The ease of communication between the } \\
\text { company and the consumers }\end{array}$ & \multirow{2}{*}{12.00} \\
\hline & & $\begin{array}{l}\text { Employee understand the consumer } \\
\text { needs }\end{array}$ & \\
\hline \multirow{3}{*}{6} & \multirow{3}{*}{$\begin{array}{l}\text { The addition of working hours } \\
\text { especially on Saturday }\end{array}$} & $\begin{array}{c}\text { Employees attend office on holidays to } \\
\text { help answering customers' } \\
\text { Questions }\end{array}$ & \multirow{3}{*}{4.98} \\
\hline & & $\begin{array}{l}\text { Responsive in handling all consumers } \\
\text { complaints }\end{array}$ & \\
\hline & & $\begin{array}{l}\text { The ease of } \\
\text { Communication between the company } \\
\text { and the consumers }\end{array}$ & \\
\hline \multirow{2}{*}{7} & \multirow{2}{*}{$\begin{array}{l}\text { Provide vacant land for the } \\
\text { establishment of the public facilities }\end{array}$} & Availability of Worship Facilities & \multirow{2}{*}{2.07} \\
\hline & & Availability of open space / green & \\
\hline
\end{tabular}




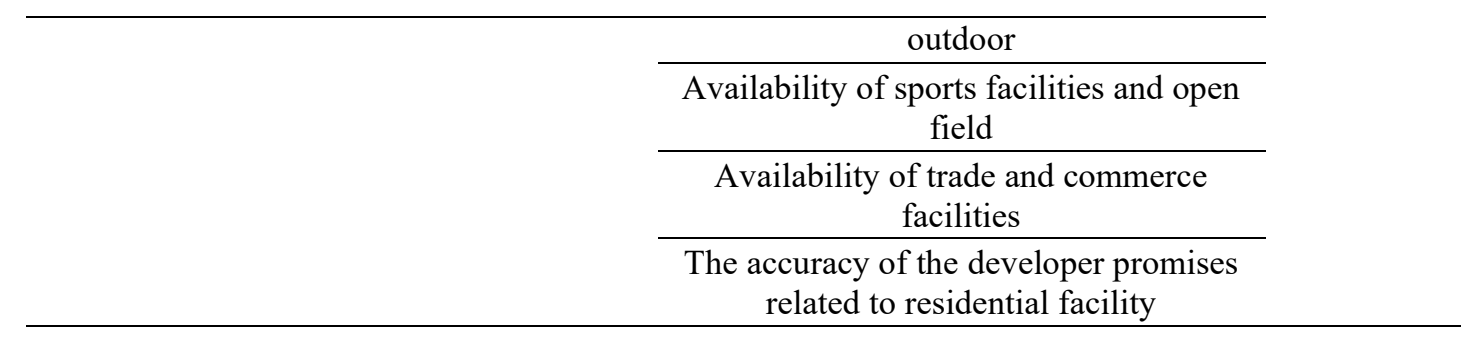

4. Technical characteristics correlation

The correlations among the technical characteristics are obtained based on an interview conducted with the marketing manager of the company. Based on the average levels of perceived condition, correlation matrix, and the relationship among the technical characteristics, a house of quality (HOQ) is constructed. The HOQ also concisely presents the priority level of the technical characteristics.

\section{Conclusions}

The research showed that the services quality provided by West Sumatera public library still not meet customer expectation. This can be seen from a negative value on each quality dimensions from gap calculation process. Furthermore, this study also produced priority of improvement actions that can be used by the library to improve their quality of service. The priority is proper construction of the library building and library standards, the addition of library infrastructure and collection, implement more effective oversight, the addition of service infrastructure, Information Management Training, adjustment and placement of personnel or officers who have competence in the implementation of service delivery and Technical Training Management Library.

Although this study has provided some interesting findings, there are still a number of limitations in this research. First, this study did not involve all kinds of services contained in the library. Second, the research done at the library occupying a temporary location so that the library has not been able to provide maximum service. Due to these limitations, it is recommended that further research is conducted, for example, conduct research for all types of services contained in the Library of West Sumatra Province, perform calculations gap 1, 2, 3 and 4 using methods Servqual and continuing the calculation of QFD to stage 2, 3 and 4.

\section{References}

1. Allen, M., Ward S.M., Wary T. and Debus-Lopez K.E. (2003) Patron-focused Services in Three US Libraries: Collaborative Interlibrary Loa. Collection Development and Acquisitions, Interlending \& Document Supply, 31(2), 138-141

2. Calvert, P.J. (1998) 'A Different Time, a Different Country: an Instrument for Measuring Service Quality in Singapore's Polytechnic Libraries'. The Journal of Academic Librarianship, 24 (4), 296-299.
3. Harwood, N. and Bydder J. (1998) 'Student Expectations of, and Satisfaction with, the University Library'. The Journal of Academic Librarianship, 24(2), 161-171.

4. Hiller, S. (2001) 'Assessing User Needs, Satisfaction, and Library Performance at the University of Washington Libraries'. Library Trends, 49(4), 605625.

5. Jordan, P. (1998) The Academic Library and Its Uers. Gower, Aldershot.

6. Kiran Kaur Pauziaah Mohamad Sossamma George, (2006),"Quality management service at the University of Malaya Library", Library Management, Vol. 27 Iss $4 / 5$ pp. $249-256$

7. Luca Petruzzellis Angela Maria D'Uggento Salvatore Romanazzi, (2006),"Student satisfaction and quality of service in Italian universities", Managing Service Quality: An International Journal, Vol. 16 Iss 4 pp. $349-364$

8. Martensen, A. and Granholdt L. (2003) 'Improving Library Users' perceived Quality, Satisfaction and Loyalty: an Integrated Measurement and Management System'. The Journal of Academic Librarianship. 29(3), 140-147.

9. Mehran Nejati Mostafa Nejati, (2008),"Service quality at University of Tehran Central Library", Library Management, Vol. 29 Iss 6/7 pp. 571 - 582

10. Nitecki, D. and Franklin B. (1999) 'New Measures for Research Libraries'. Journal of Academic Librarianship. 25(6), 484-487.

11. Snoj, B. and Petermanec, Z. (2001) 'Let users judge the quality of faculty library services', New Library World, Vol. 102, No. 9, pp.314-324

12. Shi, X., Holahan, P.J, and Jurkat, P. (2004) 'Satisfaction Formation Processes in Library Users: Understanding Multisource Effects'. The Journal of Academic Librarianship. 30(2), 122-131.

13. Thapisa, A.P.N. and Gamini, V. (1999), 'Perceptions of quality service at the university of Botswana library: what Nova says', Library Management, Vol. 20 No. 7, pp. 373-83. 